\title{
Soil geochemistry confines microbial abundances across an arctic landscape; implications for net carbon exchange with the atmosphere
}

\author{
N. D. Gray • C. M. McCann • B. Christgen • \\ S. Z. Ahammad ·. A. Roberts $\cdot$ D. W. Graham
}

Received: 21 August 2013/Accepted: 17 May 2014/Published online: 30 May 2014

(C) The Author(s) 2014. This article is published with open access at Springerlink.com

\begin{abstract}
A large portion of the World's terrestrial organic carbon is stored in Arctic permafrost soils. However, due to permafrost warming and increased in situ microbial mineralisation of released carbon, greenhouse gas releases from Arctic soils are increasing, including methane $\left(\mathrm{CH}_{4(\mathrm{~g})}\right)$. To identify environmental controls on such releases, we characterised soil geochemistry and microbial community conditions in 13 near-surface Arctic soils collected across Kongsfjorden, Svalbard. Statistically significant correlations were found between proxies for carbonate mineral content (i.e. $\mathrm{Ca}$ and $\mathrm{Mg}$ ) and soil $\mathrm{pH}$ (Spearman rho = $0.87, p<0.001)$. In turn, $\mathrm{pH}$ significantly inversely correlated with bacterial and Type I methanotroph gene abundances across the soils $(\mathrm{r}=-0.71$,
\end{abstract}

Electronic supplementary material The online version of this article (doi:10.1007/s10533-014-9997-7) contains supplementary material, which is available to authorized users.

N. D. Gray · C. M. McCann · B. Christgen ·

S. Z. Ahammad · D. W. Graham ( $\varangle)$

School of Civil Engineering and Geosciences, Newcastle University, Newcastle upon Tyne NE1 7RU, UK

e-mail:d.graham@ncl.ac.uk

\section{S. Z. Ahammad}

Department of Biochemical Engineering and Biotechnology, Indian Institute of Technology Delhi, Hauz Khas, New Delhi, India

J. A. Roberts

Department of Geology, University of Kansas, Lawrence, KS 66045, USA $p=0.01$ and $\mathrm{r}=-0.74, p=0.006$, respectively), which also co-varied with soil phosphorous $(\mathrm{P})$ level ( $\mathrm{r}=0.79, p=0.01$ and $\mathrm{r}=0.63, p=0.02$, respectively). These results suggest that soil $\mathrm{P}$ supply, which is controlled by $\mathrm{pH}$ and other factors, significantly influences in situ microbial abundances in these Arctic soils. Overall, we conclude microbial responses to increasing 'old carbon' releases in this Arctic region are constrained by nutrient-deficiency in surface soils, with consequential impacts on the flux and composition of carbon gasses released to the atmosphere.

Keywords Biogeochemistry · Ecology ·

Mineralogy $\cdot$ Climate science $\cdot$ Methanotrophs

\section{Introduction}

Soils and sediments are the product of parent geological material from which they are derived, (Manning 2011) and, therefore, geological variation across a region will impact native soil microbial communities by influencing soil mineralogy (Loisy et al. 1999). For example, recent studies have shown that mineral composition influences the structure (Boyd et al. 2007, Carson et al. 2009) and function (Morford et al. 2011) of soil microbial communities. Such influence is critical because how soil systems respond to climate and other environmental change will depend upon underlying geological conditions that define and impact resident microbial communities. 
Arctic regions are warming at faster rates than any other part of the planet (IPCC 2007). This is of concern because a large proportion of the World's terrestrial organic carbon is stored in permafrost soils. There is growing evidence that thawed "old" carbon is being rapidly mobilised to carbon dioxide $\left(\mathrm{CO}_{2(\mathrm{~g})}\right)$ and methane $\left(\mathrm{CH}_{4(\mathrm{~g})}\right)$, increasing net gas releases to the atmosphere (Schuur et al. 2009; Koven et al. 2011; Allen et al. 2014). For example, an estimated $190 \pm 64$ Gt C of additional permafrost carbon could be released by 2200 (Schaefer et al. 2011) and a $31 \%$ increase in Arctic $\mathrm{CH}_{4(\mathrm{~g})}$ emissions was already observed between 2003 and 2007 (Bloom et al. 2010). However, whether such changes in gas releases will continue into the future will depend upon how microbial communities respond to changing environmental conditions.

This project was undertaken to quantify geochemical conditions and soil microbial communities in a diverse array of high Arctic sites across a $100 \mathrm{~km}^{2}$ region near Ny-Ålesund in Svalbard. Our goal was to determine whether general patterns exist in microbial distributions and abundances as a function of underlying geology, and then assess how key microbial functions might respond to Arctic warming. The research strategy was to focus on quantification of groups most pertinent to $\mathrm{CH}_{4(\mathrm{~g})}$ flux mitigation, which include aerobic methane-oxidizing bacteria (methanotrophs; Aronson et al. 2013), in addition to total bacteria that encompass a wider array of soil functions. Methanotrophs oxidize $\mathrm{CH}_{4}$ to $\mathrm{CO}_{2}$, biomass, and $\mathrm{H}_{2} \mathrm{O}$; are ubiquitous in aerobic surface soils; and are nature's primary biological mechanism for suppressing $\mathrm{CH}_{4(\mathrm{~g})}$ releases to the atmosphere (Hanson and Hanson 1996). However, our understanding of methanotroph ecology is incomplete because it is sometimes biased towards laboratory observations and-or field studies with limited supporting geochemical data (Nazaries et al. 2013), which this study aims to resolve within the context of regional bedrock geology.

\section{Materials and methods}

Field program and sampling

Soil core samples were collected from 13 locations distributed along the southern and northern margins of Kongsfjorden in Northwestern Spitsbergen (Fig. 1 and Supplemental Information (SI), Table S1). Cores were collected from the top $10 \mathrm{~cm}$ of the soil profile, which brackets the ground surface and the anaerobicaerobic interface (Cleveland and Liptzin 2007). During soil sampling, in situ methane flux measurements were made at each site using triplet sets of gas flux chambers placed in a triangular pattern approximately one meter apart. Gas flux chambers were comprised of glass serum bottles $(100 \mathrm{ml})$ with the base removed. For each flux measurement, bottles were crimp-sealed with butyl rubber stoppers and embedded in the soil for $1 \mathrm{~h}$. Headspace gas samples $(10 \mathrm{ml})$ were then removed with plastic syringes $(10 \mathrm{ml})$ and injected into evacuated gas sampling tubes $(12 \mathrm{ml}) . \mathrm{CH}_{4(\mathrm{~g})}$ analysis (see below) was performed within $4 \mathrm{~h}$ of sampling at the Natural Environment Research Council (NERC) field station in Ny-Alesund.

At each site, three soil cores were removed using sterile plastic syringes $(60 \mathrm{ml})$ with the luer ends removed with a flame sterilized hack saw. At highwater soil sites, pore water was also sampled, filtered and analysed for metals and isotope signatures. All sampling was performed in late August 2010 as the Arctic winter was approaching; therefore, active layer depths were about maximum for the season. On return to the NERC field lab, soil cores were frozen immediately and shipped frozen to the UK/USA home labs for detailed analyses of key soil parameters.

\section{$\mathrm{CH}_{4(\mathrm{~g})}$ and isotopic analyses}

$\mathrm{CH}_{4(\mathrm{~g})}$ was quantified by gas chromatography with flame ionization detection, using a portable SRI instruments Model 8610C Gas Chromatograph fitted with a Molecular sieve 5A packed stainless steel coil column $3^{\prime} \times 1 / 8^{\prime \prime}$ O.D. The detection limit was $1 \mathrm{ppm}$ $\mathrm{CH}_{4}$ with typical relative standard deviations on the calibration curves of $<1 \%$. Collected gas and filtered soil water samples were analysed for ${ }^{13} \mathrm{C}$ of $\mathrm{CO}_{2}$ and DIC (dissolved inorganic carbon), respectively. Water samples for $\delta^{13} \mathrm{C}$ were filtered directly into nitrogen purged air-tight microcosms, which contained $\mathrm{HgCl}$ and acidified with $100 \% \mathrm{H}_{3} \mathrm{PO}_{4}$ for extractions. Extracted gases and original gas samples were injected into a Thermo Finnigan GASBENCH II interfaced to a ThermoFinnigan MAT253 Isotope Ratio Mass Spectrometer (IRMS) operating in continuous flow mode (CF-IRMS). Isotope values are reported relative to V-PDB. 
a
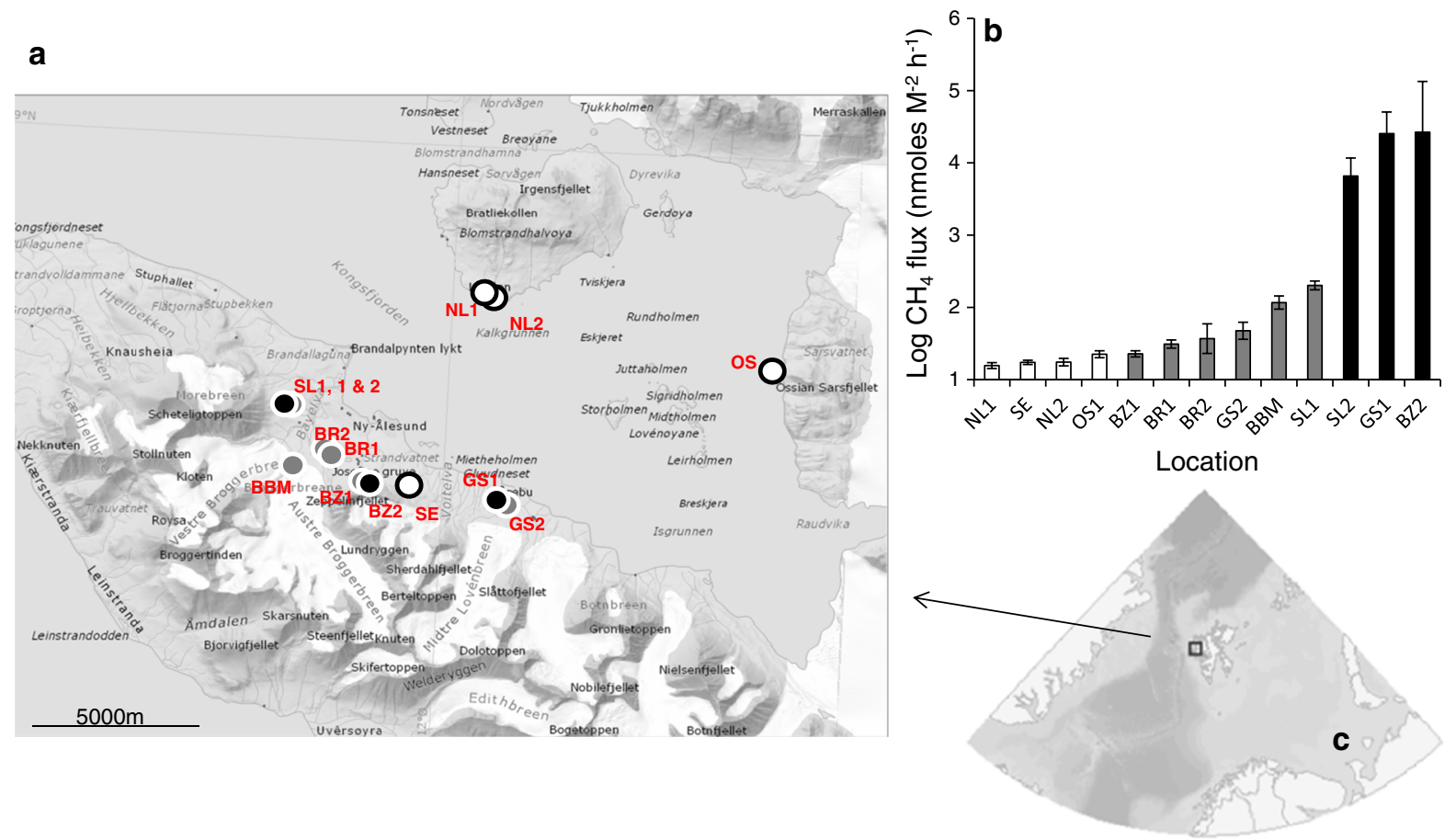

Fig. 1 a Kongsfjord sampling locations (adapted from a topographic mapping obtained from the Norwegian Polar Institute). Individual sampling sites indicated by circles and sample identification codes (see supplementary Table S1). b Methane flux data from triplicate flux chambers deployed at each of the 13 Ny-Alesund sampling sites. Error bars represent

Characterization of soil nutrients, metals and mineralogy

All soil samples were air dried, sieved to $>2 \mathrm{~mm}$ (after removing large plant debris), and homogenized prior to analysis. Soil pH was determined on soil samples suspended at a vol:vol ratio of 1:5 in deionised water. The slurry was mixed on a reciprocal shaker for $1 \mathrm{~h}$ and left to stand overnight to equilibrate then measured using a Jenway $3020 \mathrm{pH}$ meter (Jenway Ltd., UK). Soil moisture was determined in triplicate in porcelain crucibles dried to constant mass at $105^{\circ} \mathrm{C}$. Moisture content was calculated on a dry mass basis and expressed as a percentage of this mass. TOC was analysed in triplicate using a LECO CS244 Carbon analyser (LECO Instrument Ltd., UK) with an infrared detection system and reported as percentage of total dry weight.

$\mathrm{NO}_{3}-\mathrm{N}$ and $\mathrm{NH}_{4}-\mathrm{N}$ levels were determined colourimetrically after extraction for $30 \mathrm{~min}$ in $2 \mathrm{M} \mathrm{KCl}$ solution and filtration (Whatman No 42 filter paper),
$1 \times$ standard error. White, grey or black bars (or circles in a) represent sampling locations with methane flux rates of $<1.4$, 1.4-2.4 and $>2.4 \log$ nmoles $\mathrm{CH}_{4} \mathrm{M}^{-2} \mathrm{~h}^{-1}$ respectively. c Map showing the position of the Kongsfjord sampling region (indicated by box) in the Svalbard archipelago located in the North Atlantic

using a Multiskan Spectrum spectrophotometer (Thermo Scientific, UK) (Laskov et al. 2007; Shand et al. 2008), whereas total kjeldahl nitrogen (TKN) was quantified according to standard methods (Department of Environment Staff 1988). Total P was characterized on dried and homogenized samples extracted in aqua regia $\left(1: 3\right.$ for $\left.\mathrm{HNO}_{3}: \mathrm{HCl}\right)$, which was refluxed for $3 \mathrm{~h}$, filtered and diluted in $1 \% \mathrm{HNO}_{3}$ for Inductively Coupled Plasma Mass Spectrometry (Agilent 7500ce ICP-MS) analysis. Operationally defined 'available' $\mathrm{P}$ was determined on a sub-set of dried and homogenized samples using USEPA Method 1311 for determining mobility of inorganic analytes in solids (EPA 2008), whereby soils were extracted with $0.2 \mathrm{M}$ acetic acid at $\mathrm{pH} 4.9$ for $2 \mathrm{~h}$ at $25{ }^{\circ} \mathrm{C}$. Liquid samples were filtered and analysed as described for soil metals (see below). Total and 'available' $\mathrm{P}$ significantly correlated among soils tested $(p<0.05)$; however, total $\mathrm{P}$ encompasses all of the 'available' and 'unavailable' forms of $\mathrm{P}$ that are present in soils including inorganic (adsorbed, 
secondary and primary mineral forms) or organic (adsorbed and humic associated) components. The terms 'available' and 'unavailable' are operational terms used by plant physiologists, whereas microorganisms can mediate the release and transfer of $\mathrm{P}$ from all of these pools (Richardson and Simpson 2011). Therefore, total $\mathrm{P}$ was the main metric used for subsequent correlations with microbial abundances.

Soil metals were characterized on dried and homogenized samples extracted with reverse aqua regia, 3:1 $\left(\mathrm{HNO}_{3}: \mathrm{HCl}\right)$, using a DigiPrep HT 100 digestion block for $10 \mathrm{~h}$. The temperature was ramped to $95{ }^{\circ} \mathrm{C}$ over $2 \mathrm{~h}$ and then held at this temperature for $8 \mathrm{~h}$. The digested sample was then dried down and re-suspended in $1 \% \mathrm{HNO}_{3}$, filtered, diluted further with $1 \% \mathrm{HNO}_{3}$, and analysed by Inductively Coupled Plasma Optical Emission Spectroscopy (ICP-OES, PerkinElmer, Optima 5300 DV, optical emission spectrometer). An ICP standard, Cal 2 (PerkinElmer, USA) certified solution, was used for all ICP calibrations.

Soil mineralogy was determined using powdered X-ray diffraction (XRD) at the University of Kansas Crystallography Lab (USA). Soil samples were analyzed on a Bruker AXS D8 Advance X-ray diffractometer with a Bruker Lynx Eye detector and a sealedtube copper X-ray source. D-spacings for individual peaks were used to identify minerals utilizing the Bruker EVA software (a peak-matching software with standard mineral databases).

\section{Molecular microbiological analyses}

Genomic DNA was extracted from $0.5 \mathrm{~g}$ of thawed field-moist soil using BIO 101 FastDNA Spin Kit for soils (Q-BioGene, UK), and a Fast Prep Ribolyser (MP Biomedicals, USA) in triplicate, according to the manufacturer's protocol. A procedural blank was carried out using $250 \mu \mathrm{l}$ of microbiological grade filter sterilised water (Sigma, UK) in place of soil to check kits were clear of contaminants. The presence of extracted DNA was checked by agarose gel electrophoresis and was stored at $-20^{\circ} \mathrm{C}$ until further use.

Previously developed qPCR assays were used to quantify bacterial (Gray et al. 2011) and Type I and II (Martineau et al. 2010) 16S rRNA gene abundances in relation to calibration standards and DNA extraction procedural blanks. Standards were prepared from 10-fold dilution series of target DNA sequences cloned from amplified pure culture DNA with $\mathrm{R}^{2}$ values $>0.98$ in standard curves. qPCR for Type I and II methanotrophs were performed in a total reaction volume of $10 \mu \mathrm{l}$ that contained $5 \mu \mathrm{l} \mathrm{SsoFast} \mathrm{EvaGreen}$ Supermix (Bio-Rad Laboratories, USA), $0.25 \mu \mathrm{l}$ of each primer (both at a concentration of 10 pmol per $\mu \mathrm{l}$ ), $3 \mu \mathrm{l}$ of molecular biology grade water (SigmaAldrich, UK) and $1.5 \mu \mathrm{l}$ of template DNA. Reactions were similar for bacterial 16S rRNA amplification, except iQ SYBR Green Supermix (Bio-Rad Laboratories, UK) was used. All qPCR reactions were carried out on a CFX96 ${ }^{\mathrm{TM}}$ Real-time System (Bio-Rad Laboratories, USA), using accompanying operation and analysis software and included an initial denaturation $\left(5 \mathrm{~min}\right.$ at $\left.95{ }^{\circ} \mathrm{C}\right)$, This step was then followed by 39PCR cycles for the bacterial primer pair (U1048F (GTGITGCAIGGIIGTCGTCA) and U1371R (ACGT CITCCICICCTTCCTC)) with $45 \mathrm{~s}$ at $95{ }^{\circ} \mathrm{C}, 45 \mathrm{~s}$ at $60.5^{\circ} \mathrm{C}$ and $45 \mathrm{~s}$ at $72{ }^{\circ} \mathrm{C}$; or 39 cycles for the Type I primer pair (U785F (GGATTAGATACCCTGGTAG) and MethT1bR (GATTCYMTGSATGTCAAGG)) with $5 \mathrm{~s}$ at $95{ }^{\circ} \mathrm{C}, 5 \mathrm{~s}$ at $55^{\circ} \mathrm{C}$ and $5 \mathrm{~s}$ at $72{ }^{\circ} \mathrm{C}$; or 40 cycles for the Type II primer pair (U785F and MethT2R (CATCTCTGRCSAYCATACCGG)) with $5 \mathrm{~s}$ at $95^{\circ} \mathrm{C}, 5 \mathrm{~s}$ at $60^{\circ} \mathrm{C}$ and $5 \mathrm{~s}$ at $72{ }^{\circ} \mathrm{C}$. Amplification of specific and non-specific products and primer dimers were checked by gel electrophoresis and melt curve analysis based on expected amplicon fragment sizes for each of the assays (U1048F/ U1371R 328 bp; U785F/MethT1bR 221 bp; U785F/ MethT2R 232 bp). For each assay, PCR inhibition was determined in each sample by comparisons of quantification cycle in serial dilutions with subsequent calculation of PCR efficiencies which were $>90 \%$.

All these qPCR assays have been used previously; however, for this study we reappraised the primer pair specificities using the RDP probe match analysis tool (Cole et al. 2007, RDP release 10). The U1048F/ U1371R primer pair (Gray et al. 2011) was found to target $92 \%$ of all bacterial sequences, consistent with its use as a total bacterial assay. U785F/MethT2R (Martineau et al. 2010; He et al. 2012) targeted sequences from the family Methylocystaceae (order Rhizobiales, Alphaproteobacteria, $95 \%$ of all matches) with the remainder targeting unclassified Rhizobiales, consistent with its use as a Type II methanotroph assay. In contrast, for U785F/ MethT1bR (Martineau et al. 2010; He et al. 2012), only $70 \%$ of matches were classified in the RDP database as the target group Methylococcaceae 
(Gammaproteobacteria). The remainder were unclassified Gammaproteobacteria. However, analysis of these non-target sequences revealed that non-Methylococcaceae were almost exclusively recovered from marine hydrothermal vents, sediments, sulphur-oxidizing biofilms and mine waters (see SI, Fig. S1).

\section{Results and discussion}

Sampling sites and baseline conditions at each site

Soil organic matter, moisture, and nutrient conditions varied broadly across sites (see SI, Tables S2 and S3). For example, the average organic matter concentration was $4.5 \pm 1.0(\mathrm{SE}) \%$, but varied 10-fold, and molar soil $\mathrm{C} / \mathrm{N}$ and $\mathrm{C} / \mathrm{P}$ ratios were $34.8 \pm 4.8$ and $275.3 \pm 63.7$ (C estimated by TOC, therefore actual $\mathrm{C}: \mathrm{N}$ and $\mathrm{C}: \mathrm{P}$ ratios were higher), respectively, with $\mathrm{C} / \mathrm{N} / \mathrm{P}$ varying by over three orders of magnitude. These ratios are high relative to typical $\mathrm{C} / \mathrm{N}$ and $\mathrm{C} / \mathrm{P}$ ratios for microbial biomass in soils (i.e., $8.6 \pm 0.3$ and $59.5 \pm 3.6$ ), respectively (Cleveland and Liptzin 2007). Therefore, $N$ and $P$ levels in Kongsfjorden soils appear low relative to typical microbial nutritional needs. These results are consistent with previous studies on Ny-Alesund soils, which indicated P was more likely limiting than $\mathrm{N}$ or $\mathrm{K}$ for plant growth (Wookey et al. 1995). Measured surface $\mathrm{CH}_{4(\mathrm{~g})}$ release rates varied by five orders of magnitude across the sites, ranging from 0.02 to $157.0 \mu$ moles $\mathrm{CH}_{4(\mathrm{~g})} \mathrm{m}^{-2} \mathrm{~h}^{-1}$ (Fig. 1), with a regional average of $16.2 \pm 12.3$ (standard error; SE) $\mu$ moles $\mathrm{CH}_{4(\mathrm{~g})}$ $\mathrm{m}^{-2} \mathrm{~h}^{-1}$. No sites were found to be net $\mathrm{CH}_{4(\mathrm{~g})}$ sinks, which was recently observed for ice-wedge polygons in Canadian High Arctic (Allen et al. 2014).

Regional geology and soil geochemistry

The chemical composition of sampled soils was quantified (see SI, Tables S2 and S3) and logtransformed metal concentrations were statistically compared among parameters. Soil $\mathrm{Ca}$ and $\mathrm{Mg}$ concentrations (Fig. 2a) showed a significant gradient among sites according to local dolomite $\left(\mathrm{MgCa}\left(\mathrm{CO}_{3}\right)_{2}\right)$ and calcite $\left(\mathrm{CaCO}_{3}\right)$ sources (indicated by X-ray diffraction, $\mathrm{XRD})$, and significantly correlated with each other $(\mathrm{Ca} /$ $\mathrm{Mg}$; Pearson correlation $=0.92, p<0.001$; SI, Table $\mathrm{S} 3)$. Ca level and $\mathrm{pH}$ also were significantly correlated across sites (Fig. 2b; Spearman correlation $=0.87$, $p<0.001$ ), which implies general relationships exist in regional soil composition, including consistent buffering of soil $\mathrm{pH}$ by carbonate minerals (Stumm and Morgan 1996).

In contrast, Ca significantly negatively correlated with Al (Fig. 2c; Spearman correlation $=-0.692$, $p<0.01$ ), whereas Al significantly positively correlated with $\mathrm{K}, \mathrm{Fe}$ and $\mathrm{Ba}$ (Fig. 2d). This pattern is explained by the fact that Kongsfjord soils are formed from the differential weathering of metamorphic carbonate and aluminosilicate rocks (Mann et al. 1986); i.e., correlation of $\mathrm{Al}$ with $\mathrm{K}, \mathrm{Fe}$, and $\mathrm{Ba}$ is consistent with weathering products, such as smectite, kaolinite and illite clay minerals, and mixed valence iron oxyhydroxides derived from mica schists. These soils are also variably enriched in biogenic carbonates inferred from isotopic signatures (SI, Table S2).

Weaker correlations were seen between underlying lithology and other physicochemical data, such as moisture content, organic carbon, nitrogen speciation, and trace metals, although $\mathrm{Ca}$ levels and $\mathrm{pH}$ displayed a patterned relationship with total $\mathrm{P}$. Specifically, $\mathrm{P}$ levels were highest at intermediate $\mathrm{Ca}$ concentrations when $\mathrm{pH}>6$ and $\mathrm{P}$ negatively correlated with increasing $\mathrm{Ca}$ and $\mathrm{pH}$ values $(\mathrm{r}=-0.74, p=0.005$ and $\mathrm{r}=-0.66, p=0.02$, respectively, Fig. 3). One soil with $\mathrm{pH}<6$ had a surprisingly low P level. Given no phosphate minerals were seen detected in these soils, data are consistent with documented phosphate sorption to and retention by iron oxides or clay minerals (Edzwald et al. 1976; Geelhoed et al. 1997; Neff et al. 2006), characterised by $\mathrm{P}$ levels varying with $\mathrm{pH}$ (Devau et al. 2009) and Ca (a proxy for soil carbonates) in an inverted U-shaped pattern as was observed here.

Total bacterial and methanotroph abundances among sampling sites

Total bacteria (Gray et al. 2011) and Type I and II methanotroph (Martineau et al. 2010) 16S rRNA gene abundances were quantified across Kongsfjord soils to compare resident microbial communities with geochemical conditions. Total bacterial abundances varied by about one order of magnitude across the 13 sites in near surface soils, ranging from $1.6 \times 10^{8}$ to $3.2 \times 10^{9} 16 \mathrm{~S}$ rRNA gene abundance $\mathrm{g}_{(\text {dry soil) }}^{-1}$. Type I methanotrophs dominated over Type II signals at all sites (see SI, Table S4). A similar dominance of Type I 

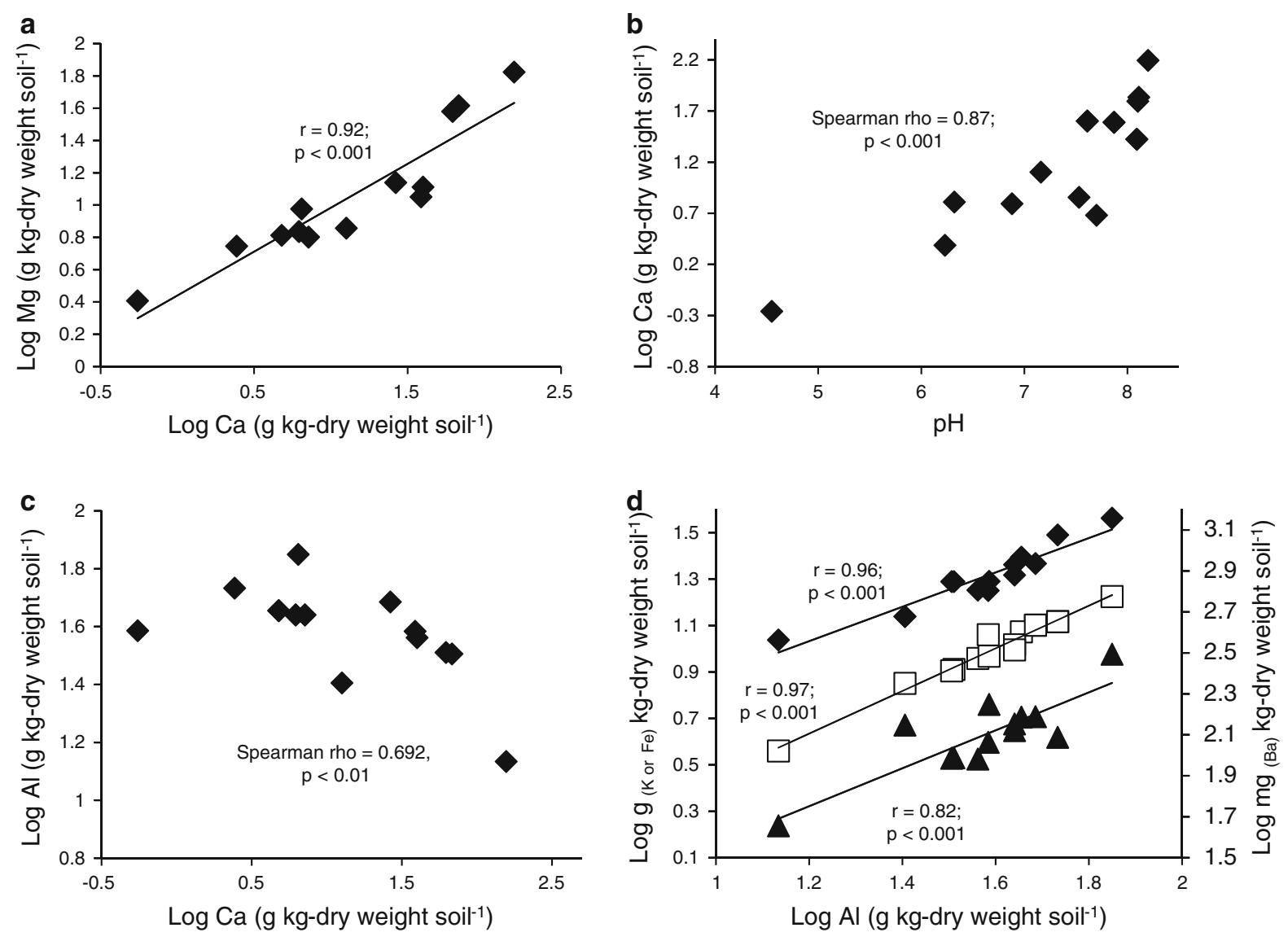

Fig. 2 Bivariate correlations of metal compositions and $\mathrm{pH}$ indicative of the distributions and effect of carbonate and clay minerals across the 13 Kongsfjord soils. a Crossplot of $\mathrm{Ca}$ and Mg. b Crossplot of $\mathrm{Ca}$ and $\mathrm{pH}$. c Crossplot of $\mathrm{Ca}$ and $\mathrm{Al}$. d Crossplots of $\mathrm{Al}$ with $\mathrm{K}$ (closed diamonds), $\mathrm{Fe}$ (closed

triangles) and $\mathrm{Ba}$ (open squares). The $p$ values indicate the significance of linear (Pearson) or non-linear (Spearman) correlation coefficients for pairs of variables (SPSS Statistics version 19 ; IBM)

strains in Arctic soils has been seen at Canadian (Martineau et al. 2010), Siberian (Liebner and Wagner 2007) and Svalbard (Graef et al. 2011; Tveit et al. 2013) sites. Corroboration of Type I dominance was seen in metatranscriptomic data for Svalbard peat soils, which showed that the Type I methanotroph Methylobacter tundripaludum (among targets for our Type I qPCR assay) represented $\sim 2.4 \%$ of total transcripts and a general absence of transcription products for type II strains (Tveit et al. 2013).

A mechanistic understanding of how geochemistry influences microbial abundances

Previous reports have suggested that Type I methanotrophs are often better adapted to growth at lower $\mathrm{CH}_{4(\mathrm{~g})}$

concentrations, whereas Type II methanotrophs appear to favour higher $\mathrm{CH}_{4(\mathrm{~g})}$ concentrations and-or proliferate when nitrogen and oxygen levels are lower (Hanson and Hanson 1996; Kolb 2009; Graef et al. 2011; Mackelprang et al. 2011). In general, methanotrophs appear to have fairly distinct habitat preferences defined by differential requirements for secondary resources, such as oxygen, $\mathrm{N}$ and $\mathrm{P}$ (Hanson and Hanson 1996; Kim and Graham 2003; Nazaries et al. 2013), and key trace metals, such as iron $(\mathrm{Fe})$ and copper $(\mathrm{Cu})$, needed for different methane-oxidizing enzymes (Knapp et al. 2007; Chi-Fru et al. 2011). Therefore, we examined correlations of microbial abundances and geochemical variables among our samples to determine whether regional geochemical variations explain observed regional microbial distributions. 
Type I methanotroph abundances were highly correlated with total bacterial levels across our sites (Fig. 4a; $r=0.94, p<0.001$ ). This correlation is consistent with parallel competition for different limiting resources (e.g. N, P) and-or Type I methanotrophs may be acting as pseudo-primary producers by fixing $\mathrm{CH}_{4(\mathrm{~g})}-\mathrm{C}$ into the near-surface

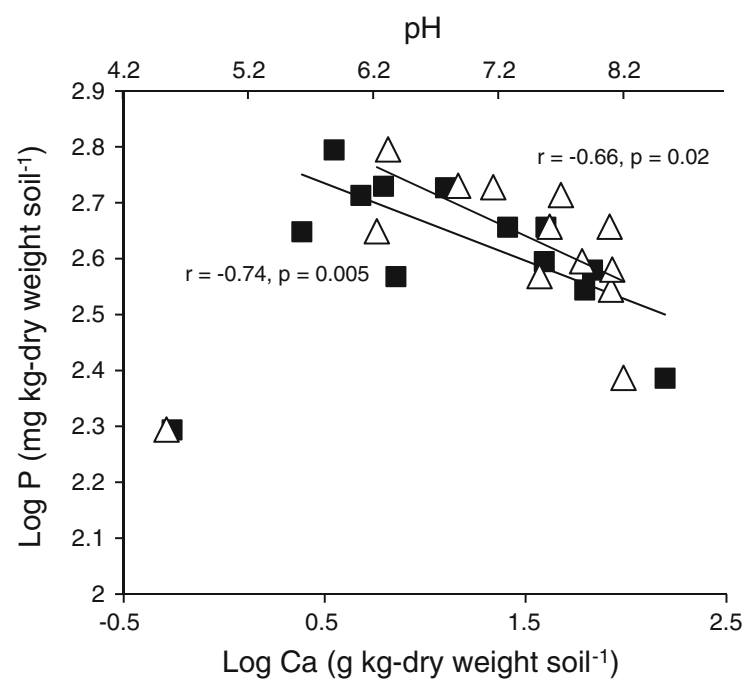

Fig. 3 Relationships between $\mathrm{Ca}$ concentrations (closed squares) and $\mathrm{pH}$ (open triangles) relative to soil $\mathrm{P}$ across the 13 Kongsfjord sampling sites

a

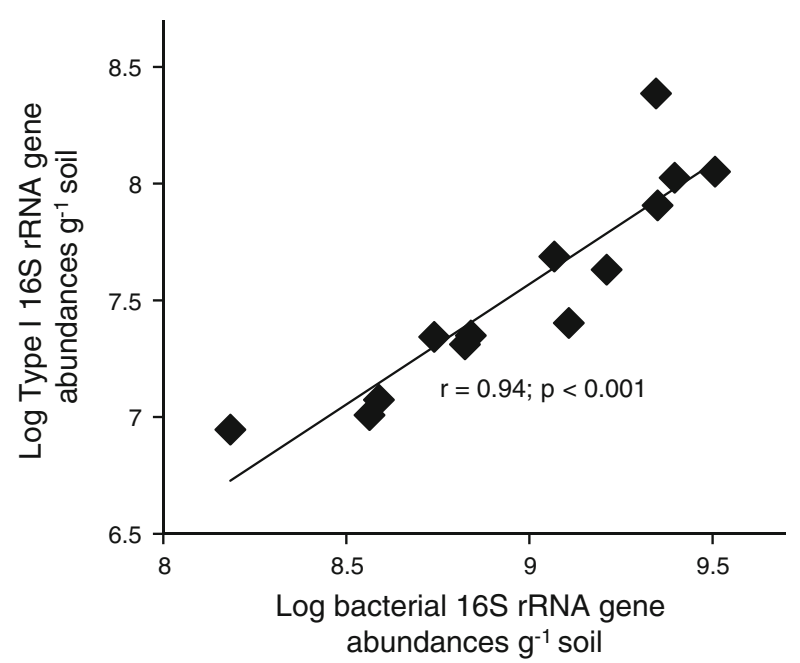

Fig. 4 a Crossplot of bacterial and Type I methanotroph rRNA gene abundances. b Crossplot of bacterial (closed squares) and Type I methanotroph (open diamonds) rRNA gene abundances soil environment. Further, both microbial signals displayed a similar patterned relationship with soil $\mathrm{pH}$ with maximum abundances at intermediate $\mathrm{Ca}$ values and $\mathrm{pH}$ (Fig. 4b). In turn, bacterial and Type I abundances significantly linearly correlated with soil $\mathrm{P}$ (Fig. 5, $\mathrm{r}=0.79, p=0.01$ and $\mathrm{r}=0.63$, $p=0.02$, respectively) that suggests potential P-limitation for microbial abundances, consistent with regional differences in soil geochemistry.

In support of this conclusion, no significant correlations were seen between any $\mathrm{N}$ source (nitrate, nitrite, TKN and ammonia), and total bacterial or Type I methanotroph abundances. Additionally, no correlation was seen between Type I gene abundances and $\mathrm{CH}_{4(\mathrm{~g})}$ flux data. It should be noted that this lack of correlation between microbial abundances and $\mathrm{CH}_{4(\mathrm{~g})}$ flux data also may result from the "snap shot" nature of the $\mathrm{CH}_{4(\mathrm{~g})}$ data collected here (which might not mirror $\mathrm{CH}_{4(\mathrm{~g})}$ flux over longer timeframes). However, our strong correlations with soil $\mathrm{P}$ suggest that lithological factors may supersede $\mathrm{CH}_{4(\mathrm{~g})}$ supply in local importance. To assess the relative effect of $\mathrm{P}$ level on soil methanotroph abundances, selected soils from the study were provided $\mathrm{P}$ supplements in microcosms (with excess $\mathrm{CH}_{4(\mathrm{~g})}$ ) and monitored over time. $\mathrm{P}$ additions generally increased methanotroph levels and $\mathrm{CH}_{4(\mathrm{~g})}$ oxidation rates in soils tested (e.g., see SI, Fig. S2).

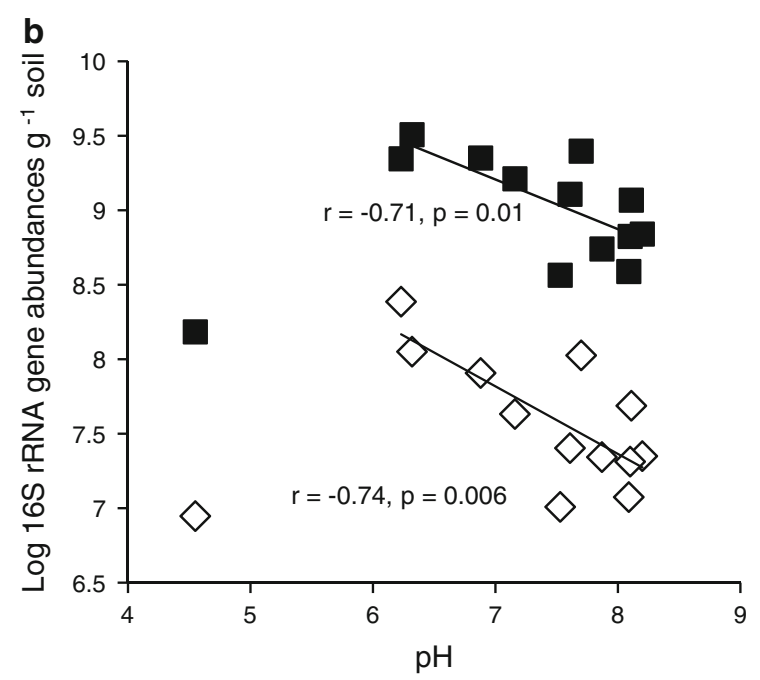

with soil $\mathrm{pH}$. The $\mathrm{r}$ and $p$ values, respectively, indicate the strength and significance of the linear correlations 


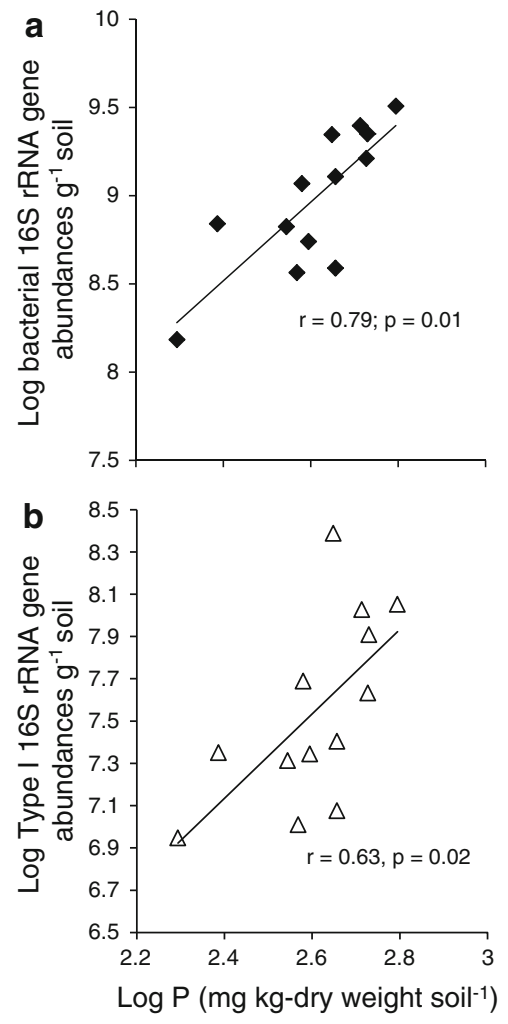

Fig. 5 Crossplots of a bacterial and b Type I methanotroph rRNA gene abundances with soil $\mathrm{P}$. The $\mathrm{r}$ and $p$ values, respectively, indicate the strength and significance of the linear correlations

In contrast, Type II methanotroph levels across the Svalbard sites did not correlate with any measured soil parameter, including soil $\mathrm{P}$, suggesting this guild is not P-limited and-or Type II levels are controlled by other or multiple factors. Type II abundances also did not significantly correlate with measured $\mathrm{CH}_{4}(\mathrm{~g})$ oxidation rates. Whereas, Type II levels tended to be higher at sites with higher moisture; lower apparent oxygen levels; elevated ammonium relative to nitrate; and higher $\mathrm{C} / \mathrm{N}$ ratios, which hints that Type II strains are more common when $\mathrm{N}$ is lower and redox conditions are reduced. Previous studies suggest Type II strains may be less abundant in Arctic settings (Liebner and Wagner 2007; Martineau et al. 2010; Graef et al. 2011), which is consistent with our results. This does mean type II strains play no role in $\mathrm{CH}_{4}(\mathrm{~g})$ oxidation at Arctic sites, but Tveit et al. (2013) found an absence of Type II transcription products in a Svalbard soil near our sampling sites. Therefore, Type I strains are both most abundant and appear to be most active in this region, although additional transciptomic work at Svalbard sites would be helpful to better delineate the activity of type II strains in Arctic $\mathrm{CH}_{4}(\mathrm{~g})$ oxidation.

Local geochemistry (e.g., $\mathrm{pH}, \mathrm{P}$ etc.) controlling microbial abundances has been documented elsewhere. For example, soil $\mathrm{pH}$ significantly influences both microbial community composition (Fierer and Jackson 2006; Männistö et al. 2007; Lauber et al. 2009) and abundance in soils (Kolb 2009; Rousk et al. 2010), including Arctic soils. Further, Chu et al. (2010) reported microbial species diversity and $\mathrm{pH}$ can follow an inverted $U$ shape, which is a similar to abundance patterns observed here. However, such observations do not provide a mechanistic explanation for specific geochemical influences on soil microbial conditions; whereas new data here show that explicit soil forming processes and differences in soil mineralogy significantly correlate with local $\mathrm{pH}$ and $\mathrm{P}$ on regional scale, which in turn, significantly correlates with both bacterial and Type I gene abundances. Further, correlation of microbial abundances with soil $\mathrm{P}$ is consistent with the known ability of microbial communities to mediate the transfer of $\mathrm{P}$ between pools regarded as either 'unavailable' or 'available' (via a range of enzymatic and chemical leaching mechanisms; Richardson and Simpson 2011) and also with low $\mathrm{C} / \mathrm{P}$ ratios across the region.

Implications for carbon release from thawing permafrost soils

Microbial activity in permafrost soils is strongly influenced by seasonal thawing, which defines the depth of the biologically active layer and carbon availability, whereas local water drainage that impacts redox conditions (Fig. 6; Schuur et al. 2008). Obligate aerobes, such as methanotrophs, generally reside near the soil surface, whereas anaerobes tend to be deeper in the soil profile (Aronson et al. 2013; Tveit et al. 2013). However, beyond this general observation, less is known about what controls microbial abundances and activity in Arctic regions (Liebner and Wagner 2007; Martineau et al. 2010), limiting our ability to validate greenhouse gas flux models for application at larger scales (Koven et al. 2011).

To assess the implications of the new data here, one must consider how seasonal thawing and potential warming influences the mobility of the carbon in Arctic soils. When permafrost thaws, the frozen 


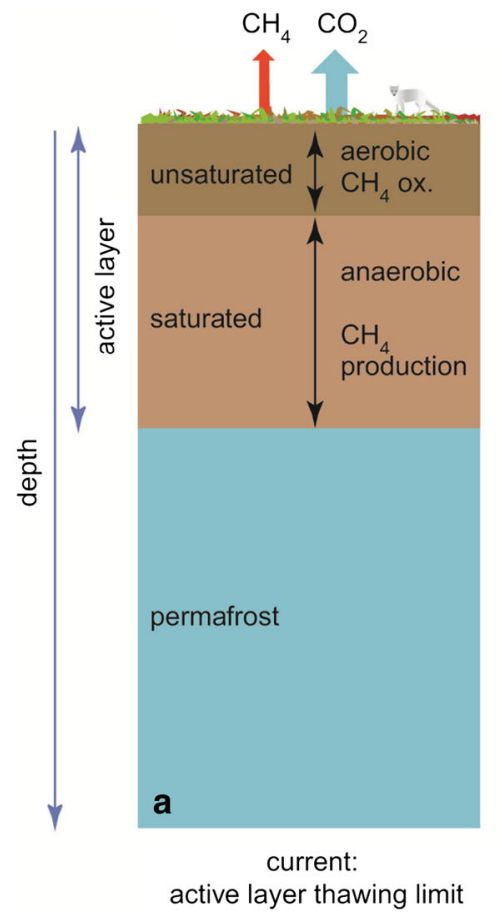

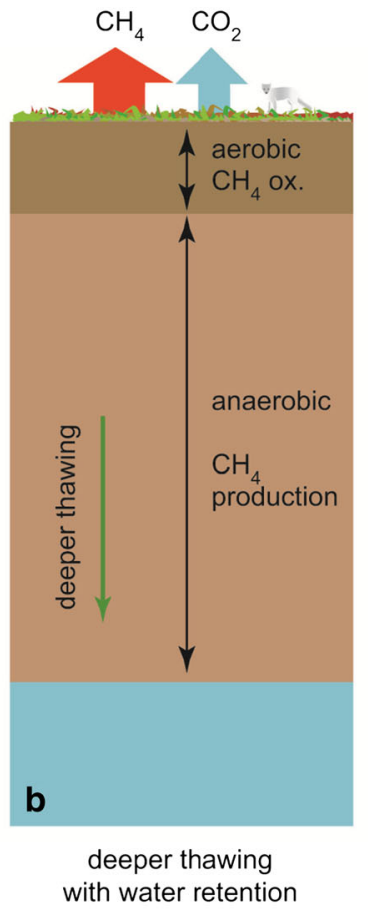

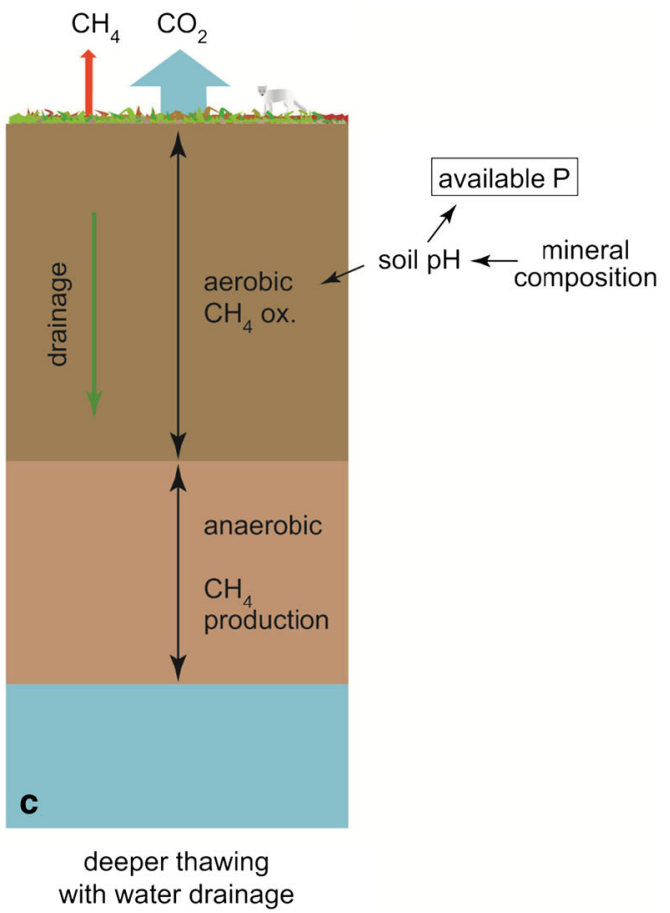

Fig. 6 Schematic of a typical high Arctic soil profile (a) and the conceptual impact of warming on methane $\left(\mathrm{CH}_{4(\mathrm{~g})}\right)$ and $\left(\mathrm{CO}_{2(\mathrm{~g})}\right)$ released to the atmosphere (b and $\mathbf{c}$ ). Soil layers include an aerobic unsaturated near-surface soil above the water table, an anaerobic saturated soil layer below the water table (above the permafrost), and frozen soils within the permafrost. Sampling depth in this study always was into the anaerobic saturated layer, but above the permafrost, which captured the primary methanotroph habitat. The actual position of the water table depends on local drainage and permafrost thaw depth at each site. Methane

organic $\mathrm{C}$ has three main fates: (1) re-incorporation into the permafrost upon re-freezing; (2) microbial decomposition to $\mathrm{CO}_{2(\mathrm{~g})}$ (under aerobic conditions) or $\mathrm{CO}_{2(\mathrm{~g})}$ and $\mathrm{CH}_{4(\mathrm{~g})}$ (under anaerobic conditions) that are emitted to the atmosphere; or (3) movement to alternate terrestrial and marine $\mathrm{C}$-pools, including sequestration of biogenic $\mathrm{CO}_{2(\mathrm{~g})}$ into the soil. Therefore, microbial decomposition of thawed carbon is critical to rates of carbon mobilisation and release to the atmosphere, which we show here may be controlled by underlying geological conditions that influence available $P$.

Focusing on methanotrophs, we speculate that as permafrost warms, more $\mathrm{CH}_{4(\mathrm{~g})}$ will be biogenically produced at depth (e.g., in poorly drained soils: Koven et al. 2011; Mackelprang et al. 2011; Allen et al. 2014). However, our data also imply that it is unlikely methanotroph abundances will respond to this increased is produced in the anaerobic layer and diffuses up through the aerobic layer where methanotrophs oxidise $\mathrm{CH}_{4(\mathrm{~g})}$ to $\mathrm{CO}_{2}$ and $\mathrm{H}_{2} \mathrm{O}$. However, methanotroph abundances are constrained by soil $\mathrm{P}$ conditions, which vary as a function of $\mathrm{pH}$ and mineral composition. The position of the water table dictates the depth of aerobic layer. If Arctic warming continues and permafrost thawing deepens, a greater amount of labile carbon will be emitted as $\mathrm{CH}_{4(\mathrm{~g})}$ where drainage is poor (b), whereas labile carbon will be emitted as $\mathrm{CO}_{2(\mathrm{~g})}$ in more well-drained soils (c)

$\mathrm{CH}_{4(\mathrm{~g})}$ supply due to secondary nutrient imitation. Consequently, more $\mathrm{CH}_{4(\mathrm{~g})}$ relative to $\mathrm{CO}_{2(\mathrm{~g})}$ will be released to the atmosphere (see Fig. $6 \mathrm{~b}$ ) because the aerobic methanotroph layer is capped by the soil surface above and anaerobic conditions below, and this layer is P-limited due to intense competition (see discussion of Fig. 4a) and a restricted habitat volume. Clearly, a constricted methanotroph habitat volume will pertain less to well-drained soils (Fig. 6c). However, given short Arctic summers and typical characteristics of Arctic locales with soil cover, seasonally poor drainage is not uncommon, making Fig. $6 \mathrm{~b}$ a common scenario.

\section{Conclusions}

Our results are consistent with previous data on Arctic biological productivity in soils. For example, it was 
seen that neutral $\mathrm{pH}$ soils in Polar regions are more nutrient-rich than acidic or alkaline soils, which clearly impacts Polar vegetation (Walker et al. 2005). Analogously, our data show pH and specific metals influence microbial community size and distribution, and explains why soils with high ambient $\mathrm{CH}_{4(\mathrm{~g})}$ levels do not necessarily have the highest methanotroph or total bacterial abundances. Our results do not address short-term effects, such as reported in recent metagenomic soil studies on permafrost thawing (Mackelprang et al. 2011), but they confirm the potential for greater levels of labile carbon released as $\mathrm{CH}_{4(\mathrm{~g})}$ to the atmosphere due to Arctic warming and increased methanogenesis (Allen et al. 2014; Koven et al. 2011). This has implications to all climatic warming research, especially forecasting, because results imply methanotrophic responses may be constrained by secondary nutrient levels, resulting in increased greenhouse gas releases in the future.

Acknowledgments Financial support was provided by the Natural Environment Research Council (Grants NE/F00608X/1 and NE/F00608X/1) to DWG and NDG and the University of Kansas General Research Fund (JAR). We thank the Kings Bay NERC Arctic Research Station and Nick Cox for his invaluable assistance. We also thank Profs Steffen Berg, Mette Svenning and Peter Frenzel for assistance during early reconnaissance of the sampling sites.

Open Access This article is distributed under the terms of the Creative Commons Attribution License which permits any use, distribution, and reproduction in any medium, provided the original author(s) and the source are credited.

\section{References}

Allen J, Ronholm J, Mykytcszuk NCS, Greer CW, Onstott TC, Whyte LG (2014) Methanogen community composition and rates of methane consumption in Canadian High Arctic permafrost soils. Environ Microbiol Rep 6:136-144

Aronson EL, Allison SD, Helliker BR (2013) Environmental impacts in the diversity of methane-cycling microbes and their resultant function. Front Microbiol 4:225. doi:10. 3389/fmicb.2013.00225

Bloom AA, Palmer PI, Fraser A, Reay DS, Frankenberg C (2010) Large-scale controls of methanogenesis inferred from methane and gravity space borne data. Science 327:322-325

Boyd ES, Cummings DE, Geesey GG (2007) Mineralogy influences structure and diversity of bacterial communities associated with geological substrata in a pristine aquifer. Microb Ecol 54:170-182
Carson JK, Campbell L, Rooney D, Clipson N, Gleeson DB (2009) Minerals in soil select distinct bacterial communities in their microhabitats. FEMS Microbiol Ecol 67:381-388

Chi-Fru E, Gray ND, McCann C, Baptista JdeC, Christgen B, Talbot HM, El Ghazouani A, Dennison C, Graham DW (2011) Effects of copper mineralogy and methanobactin on cell growth and sMMO activity in Methylosinus trichosporium OB3b. Biogeosciences 8:1-8

Chu H, Fierer N, Lauber CL, Caporaso JG, Knight R, Grogan P (2010) Soil bacterial diversity in the Arctic is not fundamentally different from that found in other biomes. Environ Microbiol 12:2998-3006

Cleveland CC, Liptzin D (2007) C:N:P stoichiometry in soil: is there a "Redfield ratio" for the microbial biomass? Biogeochemistry 85:235-252

Cole JR, Chai B, Farris RJ, Wang Q, Kulam-Syed-Mohideen AS, McGarrell DM et al (2007) The ribosomal database project (RDP-II): introducing myRDP space and quality controlled public data. Nucl Acids Res 35:D169-D172. doi:10.1093/nar/gk1889

Department of Environment Staff (1988) Kjeldahl nitrogen in waters: 1987. HMSO Books, London

Devau N, le Cadre E, Hinsinger P, Jaillard B, Gaerard F (2009) Soil $\mathrm{pH}$ controls the environmental availability of phosphorus: experimental and mechanistic modeling approaches. Appl Geochem 24:2163-2174

Edzwald JK, Toensing DC, Leung MC-Y (1976) Phosphate adsorption reactions with clay minerals. Environ Sci Technol 10:485-490

EPA Method 1311 (2008) Test methods for evaluating solid waste: physical/chemical methods. USA EPA Publications SW-846

Fierer N, Jackson RB (2006) The diversity and biogeography of soil bacterial communities. Proc Natl Acad Sci USA 103:626-631

Geelhoed JS, Hiemstra T, van Riemsdijk WH (1997) Phosphate and sulfate adsorption on goethite: single anion and competitive sorption. Geochmi Cosmochim Acta 61:2389-2396

Graef C, Hestnes AG, Svenning MM, Frenzel P (2011) The active methanotrophic community in a wetland from the High Arctic. Environ Microbiol Rep 3:466-472

Gray ND, Sherry A, Grant RJ, Rowan AK, Hubert CRJ, Callbeck CM, Aitken CM, Jones DM, Adams JJ, Larter SR, Head IM (2011) The quantitative significance of Syntrophaceae and syntrophic partnerships in methanogenic degradation of crude oil alkanes. Environ Microbiol 13:2957-2975

Hanson RS, Hanson TE (1996) Methanotrophic bacteria. Microbiol Rev 60:439-471

He R, Wooller MJ, Pohlman JW, Quensen J, Tiedje JM, Leigh MB (2012) Shifts in identity and activity of methanotrophs in Arctic lake sediments in response to temperature changes. Appl Environ Microbiol 78:4715-4723

Intergovernmental Panel on Climate Change (IPCC) (2007) Climate change 2007: the physical science basis. Contribution of Working Group I to the fourth assessment report of the intergovernmental panel on climate change. Cambridge University Press, New York

Kim HJ, Graham DW (2003) Effects of oxygen and nitrogen conditions on the transformation kinetics of 1,2- 
dichloroethenes by Methylosinus trichosporium OB3b and its $\mathrm{sMMO}^{\mathrm{c}}$ mutant. Biodegradation 14:407-414

Knapp CW, Fowle DA, Kulczycki E, Roberts JA, Graham DW (2007) Regulation of copper acquisition and MMO gene expression by methanobactin in methane-oxidizing bacteria in the natural environment. Proc Natl Acad Sci USA 104:12040-12045

Kolb S (2009) The quest for methane-oxidizers in forest soil. Environ Microbiol Rep 1:336-346

Koven CD, Ringeval B, Friedlingstein P, Ciais P, Cadule P, Khvorostyanov D et al (2011) Permafrost carbon-climate feedbacks accelerate global warming. Proc Natl Acad Sci USA 108:14769-14774

Laskov C, Herzog C, Lewandowski J, Hupfer M (2007) Miniaturized photometrical methods for the rapid analysis of phosphate, ammonium, ferrous iron, and sulfate in pore water of freshwater sediments. Limnol Oceanogr Methods 5:63-71

Lauber CL, Hamady M, Knight R, Fierer N (2009) Pyrosequencing-based assessment of soil $\mathrm{pH}$ as a predictor of soil bacterial community composition at the continental scale. Appl Environ Microbiol 75:5111-5120

Liebner S, Wagner D (2007) Abundance, distribution and potential activity of methane oxidizing bacteria in permafrost soils from the Lena Delta, Siberia. Environ Microbiol 9:107-117

Loisy C, Verrecchia EP, Dufour P (1999) Microbial origin for pedogenic micrite associated with a carbonate paleosol (Champagne, France). Sed Geol 126:193-204

Mackelprang R, Waldrop MP, DeAngelis KM, David MM, Chavarria KL, Blazewicz SJ et al (2011) Metagenomic analysis of a permafrost microbial community reveals a rapid response to thaw. Nature 480:368-371

Mann DH, Sletten RS, Ugolini FC (1986) Soil development at Kongsfjorden, Spitsbergen. Polar Res 4:1-16

Manning DAC (2011) Biota-mineral interactions. In: Ritz K, Young I (eds) Architecture and biology of soils: life in inner space. CAB International, Wallingford, pp 104-117

Männistö MK, Tiirola M, Häggblom MM (2007) Bacterial communities in Arctic fjelds of Finnish Lapland are stable but highly $\mathrm{pH}$ dependent. FEMS Microbiol Ecol 59: $452-465$

Martineau C, Whyte LG, Greer CW (2010) Stable isotope probing analysis of the diversity and activity of methanotrophic bacteria in soils from the Canadian high Arctic. Appl Environ Microbiol 76:5773-5784
Morford SL, Houlton BZ, Dahlgren RA (2011) Increased forest ecosystem carbon and nitrogen storage from nitrogen rich bedrock. Nature 477:78-81

Nazaries L, Murrell JC, Millard P, Baggs L, Singh BK (2013) Methane, microbes and models: fundamental understanding of the soil methane cycle for future predictions. Environ Microbiol 15:2395-2417

Neff JC, Reynolds R, Sanford RL Jr, Fernandez D, Lamo P (2006) Controls of bedrock geochemistry on soil and plant nutrients in Southeastern Utah. Ecosystems 9:879-893

Richardson AE, Simpson RJ (2011) Soil microorganisms mediating phosphorus availability. Plant Physiol 156: 989-996

Rousk J, Bååth E, Brookes PC, Lauber CL, Lozupone C, Caporaso JG et al (2010) Soil bacterial and fungal communities across a $\mathrm{pH}$ gradient in an arable soil. ISME J 4:1340-1351

Schaefer K, Zhang T, Bruhwiler L, Barret AP (2011) Amount and timing of permafrost carbon release in response to climate warming. Tellus 63B:165-180

Schuur EAG, Bockheim J, Canadell JG, Euskirchen E, Field CB, Goryachkin SV et al (2008) Vulnerability of permafrost carbon to climate change: implications for the global carbon cycle. Bioscience 58:701-713

Schuur EAG, Vogel JG, Crummer KG, Lee H, Sickman JO, Osterkamp TE (2009) The effect of permafrost thaw on old carbon release and net carbon exchange from tundra. Nature 459:556-559

Shand CA, Williams BL, Coutts G (2008) Determination of $\mathrm{N}$-species in soil extracts using microplate techniques. Talanta 74:648-654

Stumm W, Morgan JJ (1996) Aquatic chemistry, 3rd edn. Wiley, New York

Tveit A, Schwacke R, Svenning MM, Urich T (2013) Organic carbon transformations in high-Arctic peat soils: key functions and microorganisms. ISME J 7:299-311

Walker DA, Raynolds MK, Daniëls FJA, Einarsson E, Elvebakk A, Gould WA et al (2005) The circumpolar arctic vegetation map. J Veg Sci 16:267-282

Wookey RA, Robinson CH, Parsons AN, Welker JM, Press MC, Callaghan TV, Lee JA (1995) Environmental constraints on the growth, photosynthesis and reproductive development of Dryas octopetala at a high Arctic polar semidesert, Svalbard. Oecologia 102:478-489 